\title{
A Spectroscopic Study on Singlet Oxygen Production from Different Reaction Paths Using Solid Inorganic Peroxides as Starting Materials
}

\author{
Qingwei Li, ${ }^{*}$ Fang Chen, Weili Zhao, Mingxiu Xu, Benjie Fang, Yuelong Zhang, Liping Duo, Yuqi Jin, and Fengting Sang \\ Laboratory of Chemical Lasers, Dalian Institute of Chemical Physics, Chinese Academy of Sciences, Dalian 116023, China \\ "E-mail: liqw@icp.acen \\ Received January 11, 2007
}

\begin{abstract}
Using solid inorganic peroxides (including $\mathrm{L}_{2} \mathrm{O}_{2}, \mathrm{Na}_{2} \mathrm{O}_{2}, \mathrm{SrO}_{2}$ and $\mathrm{BaO}_{2}$ ) as starting materials, three reaction paths for singlet oxygen $\left({ }^{\prime} \mathrm{O}_{2}\right.$ ) production were developed and studied. Their ${ }^{1} \mathrm{O}_{2}$ emission spectra in the nearIR region and visible region from these reaction paths were simultaneously recorded by a near-IR sensitive Optical Multichannel Analyzer and a visible sensitive Optical Spectrum Analyzer, respectively. The comparison of their ${ }^{\prime} \mathrm{O}_{2}$ emission spectra indicated that: (1) in term of the efficiency for ${ }^{1} \mathrm{O}_{2}$ production, the gasliquid-solid reaction path (in which $\mathrm{Cl}_{2}$ or $\mathrm{IICl}$ and $\mathrm{I}, \mathrm{O}$ reacted with the solid inorganic peroxides suspension in $\mathrm{CCl}_{4}$ ) was prior to the gas-solid reaction path (in which $\mathrm{Cl}_{2}$ or IICl reacted with the solid inorganic peroxides suspension in $\mathrm{CCl}_{4}$ ), but was inferior to the gas-liquid reaction path (in which $\mathrm{Cl}_{2}$ or IICl reacted with the solid inorganic peroxides solution in $\mathrm{II}_{2} \mathrm{O}$ or $\mathrm{D}_{2} \mathrm{O}$ ); (2) the alkali metal peroxides (such as $\mathrm{Li}_{2} \mathrm{O}_{2}$ and $\mathrm{Na}_{2} \mathrm{O}_{2}$ ) was prior to the alkaline earth metal peroxides (such as $\mathrm{SrO}_{2}$ and $\mathrm{BaO}_{2}$ ) as the solid reactants, and $\mathrm{Cl}_{2}$ was favorable than $\mathrm{IICl}$ as the gas reactant in efficiency for ${ }^{1} \mathrm{O}_{2}$ production in these reaction paths.
\end{abstract}

Key Words : Singlet oxygen, Peroxides, Emission spectroscopy, Reactions, Chlorine

\section{Introduction}

The development of new methods for an efficient, safe and simple production of singlet oxygen ${ }^{1} \mathrm{O}_{2}$, which includes the singlet delta state $\mathrm{O}_{2}\left({ }^{1} \Delta_{0}\right)$ and the singlet sigma state $\mathrm{O}_{2}$ $\left({ }^{1} \Sigma_{\mathrm{g}}{ }^{\prime}\right)$ above the ground state $\mathrm{O}_{2}\left({ }^{3} \Sigma_{\mathrm{g}}{ }^{-}\right)$, is of great importance due to the significant role of ${ }^{\prime} \mathrm{O}_{2}$ in many chemical and biochemical applications. ${ }^{1-9}$ Recently, Alfano and Christe ${ }^{10-12}$ had identified two previously unreported gas-solid reactions for ' ${ }^{\prime} \mathrm{O}_{2}$ production:

$\mathrm{Na}_{2} \mathrm{O}_{2}(\mathrm{~s})+2 \mathrm{HCl}(\mathrm{g}) \rightarrow 2 \mathrm{NaCl}(\mathrm{s})+\mathrm{H}_{2} \mathrm{O}(\mathrm{g})+1 / 2^{1} \mathrm{O}_{2}(\mathrm{~g})$

$\mathrm{Na}_{2} \mathrm{O}_{2}(\mathrm{~s})+\mathrm{Cl}_{2}(\mathrm{~g}) \rightarrow 2 \mathrm{NaCl}(\mathrm{s})+{ }^{\prime} \mathrm{O}_{2}(\mathrm{~g})$

The $\mathrm{Na}_{2} \mathrm{O}_{2}$ may be replaced by $\mathrm{L}_{2} \mathrm{O}_{2}$ or $\mathrm{BaO}_{2}$, and $\mathrm{HCl}$ may also be replaced by $\mathrm{HBr}$ or deuterated halide gas in the two reactions. The starting materials required for the two reactions are commercially available, moderately priced and safe to handle. Alfano and Christe $e^{10-12}$ suggested that the new reactions are attractive for chemical oxygen-iodine laser (COIL). However, the ${ }^{~} \mathrm{O}_{2}$ emission at 634 or $703 \mathrm{~nm}$ due to the transition of $2 \mathrm{O}_{2}\left({ }^{1} \Delta_{\mathrm{o}}\right) \rightarrow 2 \mathrm{O}_{2}\left({ }^{3} \mathrm{\Sigma}_{\mathrm{g}}\right)^{13}$ occurred in high ${ }^{\prime} \mathrm{O}_{2}$ concentration could not be obtained in their experiments. It implied that the efficiency of the two gas-solid reactions carried out in the fixed-bed reactor were not high, which may be caused by a small reaction surface area in the fixed-bed reactor. Additionally, Alfano and Christe's experiments $^{12}$ and our work ${ }^{14}$ implied that a large heat was released from the two gas-solid reactions carried out in the fixed-bed reactor and make a high bed temperature and liberate a large IR blackbody emission which would significantly influence the ${ }^{\prime} \mathrm{O}_{2}$ emission spectra recording.

Although the two gas-solid reactions have some unsolved questions to assess the potential application for COIL system, ${ }^{12}$ the solid inorganic peroxides provide a new chemical source of ${ }^{\prime} \mathrm{O}_{2}$ and it may be used for other chemical applications such as organic synthesis ${ }^{5.6}$ and waste water treatment ${ }^{9}$ that usually take place in aqueous solutions and in organic solvent. However, there are no study undertaken on the ${ }^{\prime} \mathrm{O}_{2}$ production from the reactions involving the water and organic solvent using solid inorganic peroxides as starting materials.

Therefore, in this study, for a further understanding the performance of ${ }^{\prime} \mathrm{O}_{2}$ production from the reactions using solid inorganic peroxides as starting materials three novel reaction paths involving the liquid water and organic solvent were developed and studied. The scheme for these reaction paths is depicted in Scheme 1. The three novel reaction paths are briefly described as follows: (1) the reaction path $\mathbf{A}$ is a gas-solid reaction, in which $\mathrm{Cl}_{2}$ reacts with the solid inor-

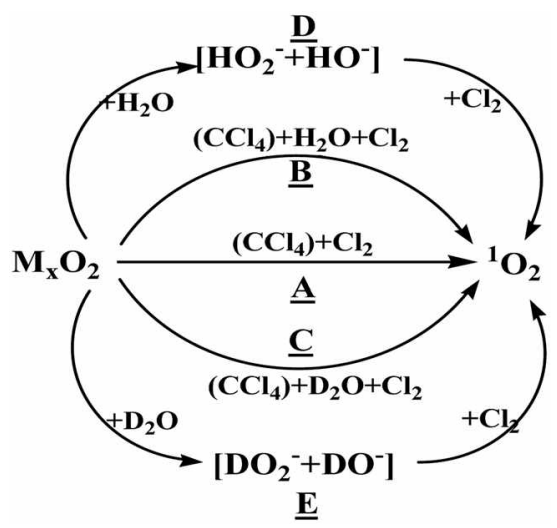

Scheme 1. Reaction paths for ' $\mathrm{O}_{2}$ production using solid inorganic peroxides as starting materials and $\mathrm{Cl}_{2}$ as gas reactant. $\mathrm{M}_{\mathrm{x}} \mathrm{O}_{2}$ include $\mathrm{Li}_{2} \mathrm{O}_{2}, \mathrm{Na}_{2} \mathrm{O}_{2}, \mathrm{SrO}_{2}$ and $\mathrm{BaO}_{2}$. 
ganic peroxides suspension in $\mathrm{CCl}_{4} ;(2)$ the reaction path $\mathrm{B}$ or $\mathbf{C}$ is a gas-solid-liquid reaction, in which $\mathrm{Cl}_{2}$ and $\mathrm{H}_{2} \mathrm{O}$ (for B) or $\mathrm{D}_{2} \mathrm{O}$ (for C) simultaneously react with the solid inorganic peroxides suspension in $\mathrm{CCl}_{4}$; (3) the reaction path $\mathbf{D}$ or $\mathbf{E}$ is a gas-liquid reaction, in which $\mathrm{Cl}_{2}$ reacts with the aqueous solution of the solid inorganic peroxides in $\mathrm{H}_{2} \mathrm{O}$ (for D) or $\mathrm{D}_{2} \mathrm{O}$ (for $\mathbf{E}$ ). The $\mathrm{CCl}_{4}$ was chosen for suspending the solid inorganic peroxides powder in these reaction paths because it has three advantages: ( 1 ) it was a favored medium for ${ }^{1} \mathrm{O}_{2}$ experiments due to a long life time of ${ }^{1} \mathrm{O}_{2}$ in $\mathrm{CCl}_{4}$ (3I $\mathrm{ms}) ;^{15}$ (2) it was also a favored solvent for many organic substrates and inert to the solid peroxides; (3) it could function as a cooling agent and keep a lower temperature of surroundings that would reduce the large IR blackbody emission. Therefore, the $\mathrm{CCl}_{4}$ in these reaction paths would make the ${ }^{1} \mathrm{O}_{2}$ generating and monitoring process more efficient and convenient. In a test apparatus, the $\mathrm{O}$ s production from the three novel reaction paths were studied by their emission spectra in the region of 1215-1325 $\mathrm{nm}$ and 530-805 $\mathrm{nm}$ which was simultaneously recorded by a near-IR sensitive Optical Multichannel Analyzer (OMA-V) and a visible sensitive Optical Spectrum Analyzer (OSA), respectively.

\section{Experimental Section}

Test Apparatus. The test apparatus for producing ' $\mathrm{O}_{2}$ and recording its emission spectra is depicted in Figure 1. The reaction/observation cell consisted of a $100 \mathrm{~mL}$ threenecked glass flask. One of its necks was connected with a glass bubbler that was linked with a gas bottle. Another neck was connected with the pressure and temperature gauge, which were linked to a computer recorder. The third neck was linked to vacuum pump through a condenser and residual gaseous chlorine absorption cell partly filled with potassium hydroxide $(\mathrm{KOH})$ solution. The reaction/observation cell was positioned on a magnetic stirrer. The ' ${ }^{\prime} \mathrm{O}_{2}$ emissions from the liquid phase in the reaction cell in the region of 1215-1325 nm and 530-805 $\mathrm{nm}$ were collected with two optical fibres which were coupled with OMA-V and OSA, respectively. The parts in the dashed rectangle were placed in a ventilation box for a safe consideration.

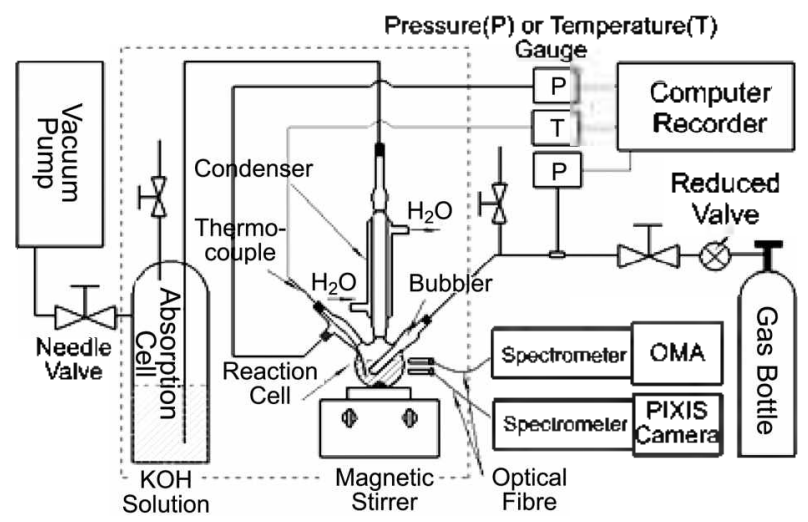

Figure 1. Schematic diagram of the test apparatus for producing singlet oxygen and measuring its emission spectra.
Reaction Procedures. The solid inorganic peroxide powders, such as $\mathrm{Li}_{2} \mathrm{O}_{2}$ (Aldrich, $90 \%$ ), $\mathrm{Na}_{2} \mathrm{O}_{2}$ (Strem Chemicals, 93\%), $\mathrm{SrO}_{2}$ (Acros, 90-95\%), $\mathrm{BaO}_{2}$ (Acros, $95 \%$ ), and other reagents all were used as purchased without further purification.

The quality of the solid inorganic peroxides powder for each experiment was $2 \mathrm{~g}$ for $\mathrm{L}_{2} \mathrm{O}_{2}$ or $6 \mathrm{~g}$ for $\mathrm{Na}_{2} \mathrm{O}_{2}, \mathrm{SrO}_{2}$ and $\mathrm{BaO}_{2}$. Typical experiment procedures are described as follows:

(1) For the reaction path $\mathbf{A}$, the solid peroxide powder was firstly added into the reaction cell, and then $60 \mathrm{~mL}$ of $\mathrm{CCl}_{4}$ was added. The reaction cell was installed into the test apparatus, evacuated, magnetically stirred, and then $\mathrm{Cl}_{2}$ or $\mathrm{HCl}$ was fed into the reaction cell for reaction through the glass bubbler which was inserted into the liquid reactant.

(2) For the reaction path $\mathbf{B}$ or $\mathbf{C}$, the solid peroxide powder was firstly added into the reaction cell, then $40 \mathrm{~mL}$ of $\mathrm{CCl}_{4}$ was added, and then $20 \mathrm{~mL}$ of diluted $\mathrm{H}_{2} \mathrm{O}$ (for $\mathbf{B}$ ) or $\mathrm{D}_{2} \mathrm{O}$ (for $\mathrm{C}$ ) was slowly added and make sure that the solid peroxide powder and $\mathrm{H}_{2} \mathrm{O}$ or $\mathrm{D}_{2} \mathrm{O}$ would not be mixed before feeding the gas reactant into reaction cell. The subsequent steps were the same as the procedure for the reaction path A.

(3) For the reaction path $\mathbf{D}$ or $\mathbf{E}, \mathrm{Li}_{2} \mathrm{O}_{2}$ or $\mathrm{Na}_{2} \mathrm{O}_{2}$ powder was firstly dissolved in $60 \mathrm{~mL}$ of $\mathrm{H}_{2} \mathrm{O}$ (for $\mathbf{D}$ ) or $\mathrm{D}, \mathrm{O}$ (for $\mathbf{E}$ ) and then formed a solution, but $\mathrm{SrO}_{2}$ or $\mathrm{BaO}_{2}$ powder with less solubility in water was firstly mixed with $60 \mathrm{~mL}$ of $\mathrm{H}_{2} \mathrm{O}$ (for D) or D,O (for $\mathbf{E}$ ) and formed a suspension, then the resultant solution or suspension was added into the reaction cell. The subsequent steps were also the same as the procedure for the reaction path $\mathbf{A}$.

(4) For a comparison, the well known reaction of basic hydrogen peroxide solution with $\mathrm{Cl}_{2}\left(\mathrm{BHP} / \mathrm{Cl}_{2}\right)$ for $\mathrm{COIL}^{1.2}$ was also conducted in the test apparatus. The procedure for the $\mathrm{BHP} / \mathrm{Cl}_{2}$ reaction was the same as the procedure for the reaction path $\mathbf{D}$ or $\mathbf{E}$ except that the solution reactant was replaced by $60 \mathrm{~mL}$ of BHP solution. The BHP solution was prepared by slowly adding the $50 \mathrm{wt} \% \mathrm{KOH}$ solution to cold $50 \mathrm{wt} \% \mathrm{H}_{2} \mathrm{O}_{2}$ over 30 -minute period while keeping the temperature of mixture below $273 \mathrm{~K}$.

All of the reactions mentioned above were carried out at room temperature with a continuous gas flow through the reaction cell while keeping the reactor total pressure in the range of 200-300 torr.

Emission Spectra Recording. The ' $\mathrm{O}_{2}$ emission spectra in the region of $530-805 \mathrm{~nm}$ from the liquid phase in the reaction cell were recorded by using the OSA with a thernoelectric air-cooling CCD PIXIS 400 camera (the temperature was kept at $203 \mathrm{~K}$ ) coupled 300 grooves $/ \mathrm{mm}$ grating blazed at 0.5 micron. The ${ }^{\prime} \mathrm{O}_{2}$ emission spectra in the region of $1215-1325 \mathrm{~nm}$ from the liquid phase in the reaction cell were recorded by using the OMA-V with a liquid nitrogencooling InGaAs camera (the temperature was kept at $173 \mathrm{~K}$ ) coupled a 600 grooves $/ \mathrm{mm}$ grating blazed at 1 micron. An uninterrupted sequence of two emission spectra from the $O S A$ and OMA-V was recorded $(100 \mathrm{~ms}$ collection time each for $\mathrm{Li}_{2} \mathrm{O}_{2}$ reaction series and $\mathrm{BHP} / \mathrm{Cl}_{2}$ reaction path, Is 

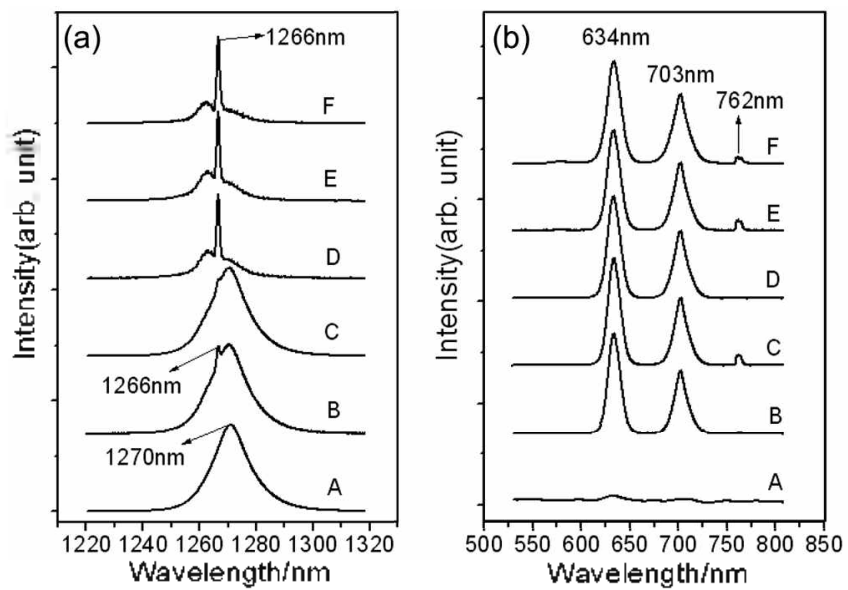

Figure 2. Emission spectra in the region of 1215-1325 nm (a) and $530-805 \mathrm{~nm}$ (b) of ${ }^{1} \mathrm{O}_{2}$ generated from the reaction path $\mathbf{A}$ to $\mathbf{E}$ using $\mathrm{Na}_{2} \mathrm{O}_{2}$ as starting matcrials and $\mathrm{Cl}_{2}$ as gas reactant, and $\mathrm{BHP}$ / $\mathrm{Cl}_{2}$ reaction $\mathbf{F}$.

collection time each for other reactions). Background subtraction was performed on all data.

\section{Results and Discussion}

Comparison of the Emission Spectra from Different Reaction Paths. Figure 2 shows the emission spectra of ' $\mathrm{O}_{2}$ generated from the reaction path $\mathbf{A}$ to $\mathbf{E}$ using $\mathrm{Na}_{2} \mathrm{O}_{2}$ as starting material and using $\mathrm{Cl}_{2}$ as gas reactant, as well as the $\mathrm{BHP} / \mathrm{Cl}$, reaction $\mathbf{F}$.

In the near-IR region of 1215-1325 nm (see Figure 2a), a characteristic ' $\mathrm{O}_{2}$ emission band at $1268 \pm 2 \mathrm{~nm}$ corresponding to the transition of $\mathrm{O}_{2}\left({ }^{1} \Delta_{2}\right) \rightarrow \mathrm{O}_{2}\left({ }^{3} \Sigma_{8}^{-}\right)^{13}$ was obtained in all of the reaction paths using $\mathrm{Na}_{2} \mathrm{O}_{2}$ as starting materials. But there were something difference in their peak wavelength and contour.

In the case of the reaction path $\mathbf{A}$ occurred in $\mathrm{CCl}_{4}$, it was a much more facile chemical reaction than the reaction path B to $\mathbf{E}$ involving $\mathrm{H}_{2} \mathrm{O}$ or $\mathrm{D}_{2} \mathrm{O}$ which were drastic reactions and caused effervescence in the course of experiments. But an obvious emission band centred at $1270 \mathrm{~nm}$ with a broad and symmetric contour caused by solvent effect of $\mathrm{CCl}_{4}{ }^{16.17}$ was still easily obtained from the reaction path $\mathbf{A}$.

In the case of the reaction path $\mathbf{D}$ or $\mathbf{E}$ involving $\mathrm{H}_{2} \mathrm{O}$ or $\mathrm{D}_{2} \mathrm{O}$, their emission bands exhibit the same peak wavelength at $1266 \mathrm{~nm}$ with a sharp and asymmetric contour that was identical with the emission contour from the $\mathrm{BHP} / \mathrm{Cl}_{2}$ reaction system $\mathbf{F}$ and the gas-solid reaction reported by Alfano and Christe. ${ }^{10.12}$ It indicates that the reaction path D or $\mathbf{E}$ have a similarly high yield of ${ }^{\prime} \mathrm{O}_{2}$ as the $\mathrm{BHP} / \mathrm{Cl}_{2}$ reaction system $\mathbf{F}$ in which some of the produced ${ }^{\prime} \mathrm{O}_{2}$ could escape from the liquid and form some gas bubbles of ${ }^{\prime} \mathrm{O}_{2}$.

In the case of the reaction path $\mathbf{B}$ or $\mathbf{C}$ simultaneously involving $\mathrm{CCl}_{4}$ and $\mathrm{H}_{2} \mathrm{O}$ or $\mathrm{D}_{2} \mathrm{O}$, their emission spectra had a combined characteristic of the emission spectra from the two reaction paths $\mathbf{A}$ and $\mathbf{D}($ or $\mathbf{E}$ ). There had a similar contour to the reaction path $\mathbf{A}$ with a peak wavelength at $1270 \mathrm{~nm}$ but a very tiny shoulder band at $1266 \mathrm{~nm}$ which was the same wavelength as those from the reaction path $\mathbf{D}$ and $\mathbf{E}$. It indicated that the ' $\mathrm{O}_{2}$ bubbles were also formed but with much less quantities in the reaction path $\mathbf{B}$ or $\mathbf{C}$ than in the reaction path $\mathbf{D}$ or $\mathbf{E}$.

In the region of $530-805 \mathrm{~nm}$ (see Figure 2b), with sufficiently high concentration, ' $\mathrm{O}_{2}$ emission spectra have two characteristic emission bands. One of its peak is at 634 or $703 \mathrm{~nm}$ corresponding to the transition of $2 \mathrm{O}_{2}\left({ }^{\prime} \Delta_{2}\right) \rightarrow$ $2 \mathrm{O}_{2}\left({ }^{3} \Sigma_{\mathrm{g}}{ }^{-}\right),{ }^{13}$ another one is a relative weak emission band at $762 \mathrm{~nm}$ corresponding to the transition of $\mathrm{O}_{2}\left({ }^{1} \Sigma_{\varepsilon}{ }^{+}\right) \rightarrow$ $\mathrm{O}_{2}\left({ }^{3} \Sigma_{8}{ }^{-}\right) \cdot{ }^{13}$ In the course of the experiments carried out in a dark room, a brilliant red glow in the reaction path $\mathbf{B}$ to $\mathbf{E}$ but only a dim red glow in the reaction path $\mathbf{A}$ could be observed. Accordingly, an obvious and strong emission band at 634 or $703 \mathrm{~nm}$ that was identical with the $\mathrm{BHP} / \mathrm{Cl}_{2}$ reaction system $\mathbf{F}$ in peak wavelength and contour was readily obtained except for the reaction path $\mathbf{A}$ in which only a very weak emission bands was obtained. The $762 \mathrm{~nm}$ emission band of ${ }^{1} \mathrm{O}_{2}$ was only detected obviously in the reaction path $\mathbf{C}$ and $\mathbf{E}$ involving $\mathrm{D}_{2} \mathrm{O}$ but with slightly stronger emission strength than in the $\mathrm{BHP} / \mathrm{Cl}$ 2 reaction system $\mathbf{F}$. It indicated that a different kinetic behavior may be occurred between the reaction paths involving the $\mathrm{H}_{2} \mathrm{O}$ and $\mathrm{D}_{2} \mathrm{O} \cdot{ }^{18}$ It also implied that the reaction path $\mathbf{C}$ and $\mathbf{E}$ involving $\mathrm{D}_{2} \mathrm{O}$ were much more efficient for ${ }^{3} \mathrm{O}$ : production than the reaction path $\mathbf{B}$ and $\mathbf{D}$ involving $\mathrm{H}_{2} \mathrm{O}$, partially due to ${ }^{\prime} \mathrm{O}_{2}$ having a longer life time in $\mathrm{D}_{3} \mathrm{O}$ than in $\mathrm{H}_{2} \mathrm{O}{ }^{19,20}$ Additionally, the $\mathrm{H}_{2} \mathrm{O}$ or $\mathrm{D}_{2} \mathrm{O}$ may act as a reaction promoter in these reaction processes, which would react with the solid inorganic peroxides and form a much more reactive species of $\mathrm{HO}_{2}^{-}$or $\mathrm{DO}_{2}^{-}$that can react with $\mathrm{Cl}_{2}$ and was converted back to $\mathrm{H}_{2} \mathrm{O}$ or $\mathrm{D}_{2} \mathrm{O}$ with a high yield of ${ }^{1} \mathrm{O}_{2}{ }^{1221}$

Based on the comparison of the emission spectra from different reaction paths, we could conclude that the three novel reaction paths involving $\mathrm{CCl}_{4}$ or $\mathrm{H}_{2} \mathrm{O}\left(\mathrm{D}_{2} \mathrm{O}\right)$ could produce ${ }^{\prime} \mathrm{O}_{2}$ with a higher efficiency than the original gassolid reaction carried out in fixed-bed reactor because the $\mathrm{C}_{2}$ emission at 634 or $703 \mathrm{~nm}$ due to the transition of $2 \mathrm{O}_{2}$ $\left({ }^{1} \Delta_{g}\right) \rightarrow 2 \mathrm{O}_{2}\left({ }^{3} \Sigma_{\mathrm{g}}^{-}\right)^{1 / 3}$ occurred in high ${ }^{\prime} \mathrm{O}_{2}$ concentration could be obtained in the reaction path $\mathbf{A}$ to $\mathbf{E}$. The comparison also indicated that the gas-liquid-solid reaction path $\mathbf{B}$ or $\mathbf{C}$ was prior to the gas-solid reaction path $\mathbf{A}$ but inferior to gas-liquid reaction path $\mathbf{D}$ or $\mathbf{E}$ in efficiency for ${ }^{\prime} \mathrm{O}_{3}$ production. Namely, the efficiency for ' $\mathrm{O}_{2}$ production from the reaction of solid inorganic peroxides with $\mathrm{Cl}_{2}$ may be enhanced greatly by the liquid $\mathrm{H}_{2} \mathrm{O}$ and $\mathrm{D}_{2} \mathrm{O}$. However, in the same time the liquid $\mathrm{H}_{2} \mathrm{O}$ and $\mathrm{D}_{2} \mathrm{O}$ would invoke a severe liquid phase quenching on ${ }^{1} \mathrm{O}_{2}$ which was the main problem encountered in the ${ }^{1} \mathrm{O}_{2}$, generator using $\mathrm{BHP} / \mathrm{Cl}_{2}$ reaction system for the COIL. ${ }^{2}$ On the contrary, these reaction paths with high efficiency for ${ }^{1} \mathrm{O}_{2}$ production may be favorable for some chemical applications (such as organic synthesis and treatment of waste water) taken placed in organic solvent or aqueous solutions. Additionally, the aqueous solution of the solid alkali metal peroxides with a similar efficiency for ${ }^{\prime} \mathrm{O}_{2}$ production as the BHP solution when they reacted with $\mathrm{Cl}_{2}$, may be used as an altemative of 
Table 1. Qualitative emission strength of ' $\mathrm{O}_{2}$ generated from reaction series using different solid inorganic peroxides as starting materials and $\mathrm{Cl}_{\Sigma}$ as the gas reactant

\begin{tabular}{|c|c|c|c|c|}
\hline $\begin{array}{l}\text { Solid } \\
\text { Peroxide }\end{array}$ & Path & $\begin{array}{l}{ }^{{ }^{1} \Delta_{q}} \rightarrow{ }^{3} \sum_{\frac{b}{5}}^{-} \\
\text {emission }\end{array}$ & $\begin{array}{c}2^{1} \Delta_{\varepsilon} \rightarrow 2 y_{i} \\
\text { emission }\end{array}$ & 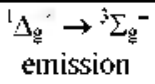 \\
\hline \multirow{5}{*}{$\mathrm{Li}_{2} \mathrm{O}_{2}$} & $\bar{A}$ & Strong & Weak & $N / A^{u}$ \\
\hline & B & Strong & Strong & Weak \\
\hline & C & Strong & Strong & Medium \\
\hline & D & Very Strong & Strong & Weak \\
\hline & $\mathbf{E}$ & Very Strong & Strong & Medium \\
\hline \multirow{5}{*}{$\mathrm{Na}_{2} \mathrm{O}_{2}$} & A & Strong & Weak & $N / A$ \\
\hline & $\mathbf{B}$ & Strong & Strong & $\mathrm{N} / \mathrm{A}$ \\
\hline & C & Strong & Strong & Medium \\
\hline & D & Strong & Strong & $\mathrm{N} / \mathrm{A}$ \\
\hline & $\mathbf{E}$ & Strong & Strong & Medium \\
\hline \multirow{5}{*}{$\mathrm{SrO}_{2}$} & $\mathbf{A}$ & Medium & $\mathrm{N} / \mathrm{A}$ & $\mathrm{N} / \mathrm{A}$ \\
\hline & B & Medium & Weak & $\mathrm{N} / \mathrm{A}$ \\
\hline & C & Strong & Weak & $\mathrm{N} / \mathrm{A}$ \\
\hline & D & Weak & $\mathrm{N} / \mathrm{A}$ & $\mathrm{N} / \mathrm{A}$ \\
\hline & $\mathbf{E}$ & Weak & $\mathrm{N} / \mathrm{A}$ & $\mathrm{N} / \mathrm{A}$ \\
\hline \multirow{5}{*}{$\mathrm{BaO}_{2}$} & $\mathbf{A}$ & Medium & $\mathrm{N} / \mathrm{A}$ & $\mathrm{N} / \mathrm{A}$ \\
\hline & B & Medium & $\mathrm{N} / \mathrm{A}$ & $\mathrm{N} / \mathrm{A}$ \\
\hline & C & Medium & $\mathrm{N} / \mathrm{A}$ & $\mathrm{N} / \mathrm{A}$ \\
\hline & D & Weak & $\mathrm{N} / \mathrm{A}$ & $N / A$ \\
\hline & $\mathbf{E}$ & Weak & $\mathrm{N} / \mathrm{A}$ & $N / A$ \\
\hline
\end{tabular}

${ }^{2}$ N/A stand for not available.

BHP for COIL because the aqueous solution of the solid alkali metal peroxides have a simpler preparation procedure than BHP solution especially for the deuterated solution (BDP). Moreover, the results from the gas-solid reaction path $\mathbf{A}$ showed that, provided with a larger reaction surface such as through a fluidized-bed reactor and the very fine solid inorganic peroxide particles, the efficiency for ' ${ }^{\prime} \mathrm{O}_{2}$ production from the gas-solid reaction may be significantly increased. These modifications would significantly reduce the deactivation of ${ }^{\prime} \mathrm{O}_{2}$ while was transferred to gas phase from the solid inorganic peroxide beds.

Comparison of the Emission Spectra Using Different Reactants. The reaction paths $\mathbf{A}$ to $\mathbf{E}$ which use other solid inorganic peroxides (such as $\mathrm{Li}_{2} \mathrm{O}_{2}, \mathrm{SrO}_{2}$ and $\mathrm{BaO}_{2}$ ) as starting materials were also tested. The results are summarized in Table 1.

Note that the $\mathrm{O}_{2}\left(\mathrm{~A}_{2}\right) \rightarrow \mathrm{O}_{2}\left({ }^{3} \mathrm{\Sigma}_{\mathrm{c}}^{-}\right)$emission from the path D and $\mathbf{E}$ using $\mathrm{Li}_{2} \mathrm{O}_{2}$ as starting material were very strong and a OMA-V saturation was experienced with the collection time of $1 \mathrm{~s}$ which was the same as for other three solid inorganic peroxides reaction series. With a shorter collection time of $100 \mathrm{~ms}$, the characteristics of their emission spectra in the region of $530-805 \mathrm{~nm}$ and $1215-1325 \mathrm{~nm}$ from $\mathrm{Li}_{2} \mathrm{O}_{2}$ reaction series are similar to the corresponding ones from the $\mathrm{Na}_{2} \mathrm{O}_{2}$ reaction series. Surprisingly, in the $\mathrm{L}_{2} \mathrm{O}_{2}$ but not in the $\mathrm{Na}_{2} \mathrm{O}_{2}$ reaction series, a very weak $762 \mathrm{~nm}$ emission band was detected in the path $\mathbf{B}$ and $\mathbf{D}$ involving $\mathrm{H}_{2} \mathrm{O}$. It indicated that the $\mathrm{L}_{2} \mathrm{O}_{2}$ was prior to $\mathrm{Na}_{2} \mathrm{O}_{2}$ for ${ }^{\prime} \mathrm{O}_{2}$ production in efficiency.

The $\mathrm{SrO}_{2}$ and $\mathrm{BaO}_{2}$ powder with high insolubility in $\mathrm{H}_{2} \mathrm{O}$ or $\mathrm{D}_{2} \mathrm{O}$, were suspended in $\mathrm{H}_{2} \mathrm{O}$ or $\mathrm{D}_{2} \mathrm{O}$ in the reaction path
D or E. Therefore, different ${ }^{1} \mathrm{O}_{2}$ emission behaviors were observed between the alkaline-earth metal peroxides $\mathrm{SrO}_{2}$ or $\left.\mathrm{BaO}_{2}\right)$ reaction series and alkali metal peroxides $\left(\mathrm{Li}_{2} \mathrm{O}_{2}\right.$ or $\mathrm{Na}_{2} \mathrm{O}_{2}$ ) reaction series. In the $\mathrm{SrO}_{2}$ or $\mathrm{BaO}_{2}$ reaction series, all of their $1270 \mathrm{~nm}$ emission bands could be obtained but all have an identical contour with the curve $\mathbf{A}$ in Figure 1a. But there were a much weaker emission strength in the path $\mathbf{D}$ and $\mathbf{E}$ than in the path $\mathbf{A}$ to $\mathbf{C}$. In the $\mathrm{SrO}_{2}$ and $\mathrm{BaO}_{2}$ reaction series, the 634 or $703 \mathrm{~nm}$ emission band was obtained only in the path $\mathrm{B}$ and $\mathrm{C}$ using $\mathrm{SrO}_{2}$ as starting material. No 762 $\mathrm{nm}$ emission band was recorded from any reaction paths using $\mathrm{SrO}_{2}$ or $\mathrm{BaO}_{2}$ as starting materials. The results indicated that a lower efficiency for ${ }^{1} \mathrm{O}_{2}$ production was obtained in the $\mathrm{SrO}_{2}$ or $\mathrm{BaO}_{2}$ reaction path $\mathbf{B}$ to $\mathbf{E}$. The reasons may be that in the reaction, the $\mathrm{Sr}(\mathrm{OH})_{2}$ or $\mathrm{Ba}(\mathrm{OH})_{2}$ with less solubility in $\mathrm{H}_{2} \mathrm{O}$ or $\mathrm{D}_{2} \mathrm{O}$ was produced and deposited on the $\mathrm{SrO}_{2}$ or $\mathrm{BaO}_{2}$ particles surface which would hinder the $\mathrm{H}_{2} \mathrm{O}$ or $\mathrm{D}_{2} \mathrm{O}$ and $\mathrm{Cl}_{2}$ from further reacting with $\mathrm{SrO}_{2}$ or $\mathrm{BaO}_{2}$ and increase the deactivation of ${ }^{\prime} \mathrm{O}_{2}$.

Although the emission signal intensity might vary somewhat from experiment to experiment, from the analysis of the ${ }^{1} \mathrm{O}_{2}$ emission bands and the comparison of their relative intensity from all of these reaction paths, we could conclude that the reactivities of the four solid inorganic peroxides as starting materials for ${ }^{1} \mathrm{O}_{2}$ production could be ranked as follows: $\mathrm{Li}_{2} \mathrm{O}_{2}>\mathrm{Na}_{2} \mathrm{O}_{2}>\mathrm{SrO}_{2}>\mathrm{BaO}_{2}$. That is to say that the $\mathrm{Li}_{2} \mathrm{O}_{2}$ was the best candidate of the solid reactant in these reaction paths for ${ }^{1} \mathrm{O}_{2}$ production, due to its highest reactivity and its highest weight efficiency $\left(\mathrm{Li}_{2} \mathrm{O}_{2}\right.$ have a highest oxygen capacity in these solid peroxides).

Also, we had monitored the ${ }^{1} \mathrm{O}_{2}$ emission spectra from all of the solid inorganic peroxides reaction series using $\mathrm{HCl}$ instead of $\mathrm{Cl}_{2}$ as the gas reactant. Alflano and Christe ${ }^{10.12}$ had obtained the $1270 \mathrm{~nm}$ emission band of ${ }^{1} \mathrm{O}_{2}$ from the gas-solid reaction of the solid alkali metal or alkaline- earth metal peroxides with the dry gaseous hydrogen halide or deuterium halide. However, in our experiments, in all of the solid inorganic peroxides reaction series using dry gaseous $\mathrm{HCl}$ as the gas reactant, no any ${ }^{1} \mathrm{O}_{2}$ emission signal was obtained either in the region of 1215-1325 nm or in the region of 530-805 $\mathrm{nm}$. The results implied that there are no detectable quantity of ${ }^{1} \mathrm{O}_{2}$ was produced from all of the reaction paths using $\mathrm{HCl}$ as the gas reactant. The reasons may be that: (1) in the case of the reaction system $\mathbf{B}$ to $\mathbf{E}$ involving liquid $\mathrm{H}_{2} \mathrm{O}$ or $\mathrm{D}_{2} \mathrm{O}$, the dry gaseous $\mathrm{HCl}$ might be predominantly react with liquid $\mathrm{H}_{2} \mathrm{O}$ or $\mathrm{D}_{2} \mathrm{O}$ and form the hydrochloric acid which would then react with the basic species through a common neutralized reaction, therefore no ${ }^{\prime} \mathrm{O}_{2}$ was produced in these experiment. ${ }^{21}(2)$ in the case of reaction path $\mathbf{A}$ carried out under our experimental conditions, the dry gaseous $\mathrm{HCl}$ may react with the solid inorganic peroxides and form the liquid hydrogen peroxide $\left(\mathrm{H}_{2} \mathrm{O}_{2}\right)$ which would undergo thermal decomposition to ground state oxygen $\left(\mathrm{O}_{2}\left({ }^{1} \Sigma_{\mathrm{g}}{ }^{+}\right)\right),{ }^{12}$ there are also no ${ }^{\prime} \mathrm{O}_{2}$ produced. The results from our experiments obviously showed that $\mathrm{Cl}_{2}$ was much favorable than $\mathrm{HCl}$ as the gas reactant for ${ }^{1} \mathrm{O}_{2}$ production in these reaction paths. 


\section{Conclusions}

The emission spectroscopic evidence, especially in which the ${ }^{\prime} \mathrm{O}_{2}$ emission bands at 634 or $703 \mathrm{~nm}$ and $762 \mathrm{~nm}$ could be easily obtained, demonstrated that the ${ }^{1} \mathrm{O}_{2}$ could be readily produced from the reactions of the solid inorganic peroxides with $\mathrm{Cl}_{2}$ through the three novel reaction paths involving liquid $\mathrm{CCl}_{4}$ or liquid $\mathrm{H}_{2} \mathrm{O}$ or $\mathrm{D}_{2} \mathrm{O}$ and these reaction paths have a higher efficiency for ' $\mathrm{O}_{2}$ production than the original gas-solid reaction reported by Alfano and Christe. $^{12}$

Moreover, our emission spectroscopic study on these reaction paths indicated that: (1) the efficiency for ' $\mathrm{O}_{2}$ production from the reaction of $\mathrm{Cl}_{2}$ with solid inorganic peroxides could be enhanced greatly by $\mathrm{H}_{2} \mathrm{O}$ or $\mathrm{D}_{2} \mathrm{O} ;(2)$ the alkali metal peroxides (such as $\mathrm{Li}_{2} \mathrm{O}_{2}$ and $\mathrm{Na}_{2} \mathrm{O}_{2}$ ) have a higher reactivity for ' $\mathrm{O}_{2}$ production than the alkaline-earth metal peroxides (such as $\mathrm{SrO}_{2}$ and $\mathrm{BaO}_{2}$ ) as the solid reactants in these reaction paths; (3) $\mathrm{Cl}_{2}$ was much favorable for ${ }^{1} \mathrm{O}_{2}$ production than $\mathrm{HCl}$ as the gas reactant in these novel reaction paths. In a conclusion, this study suggested that the solid inorganic peroxides may be used as a potential chemical source of ${ }^{1} \mathrm{O}_{2}$ for some chemical application such as COIL, organic synthesis and waste water treatment if using the suitable reaction paths.

Acknowledgment. Financial support in part from the National 863 Hi-Tech R\&D Project of People's Republic of China is gratefully acknowledged.

\section{References}

1. Kadymova, J. Proc. SPIE 2005, 5958, 5958I8-I-II.
2. Yuryshev, N. N. Quantum Electron. 1996, 26, 567.

3. Carrol, D. L.; Verdeyen, J. T.; King, D. M.; Zimmerman, J. W.; Laystrom, J. K.; Woodard, B. S.; Benavides, G. F.; Kittell, K.; Stafford, D. S.; Solomon, W. C. Appl. Phys. Lett. 2005, 86 , $111104-1-3$.

4. Belousov, V. P.; Belousova, I. M.; Grenishin, A. S.; Danilov, O. B.; Kiselev, V. M.; Kris'ko, A. V.; Mak, A. A.; Murav'eva, T. D.; Sosnov, V. N. Opt. and Spectr. 2003, $95,888$.

5. Prein, M.; Adam, W. Angew: Chem. Int. Ed. 1996, 35, 477.

6. Shim, S. C.; Song, J. S. Bull. Korean Chem. Soc. 1984, $5,265$.

7. (a) Ha, J. H.; Jung, G. Y.; Kim, M. S.; Lee, Y. H.; Shin, K.; Kim, Y. R. Bull. Korean Chem. Soc. 2001, 22, 63. (b) Ha, J. H.; Kim, M. \$.; Park, Y, I.; Ryu, \$.; Park, M.; Shin, K.; Kim, Y, R. Bldl. Korean Chem. Soc. 2002, 23,281.

8. Park, Y. T.; Lee, S. W.; Song, M. S.; Bae, J. W.; Chung, M. S. Bull. Korean Chem. Soc. 1990, $11,77$.

9. Burrows, H. D.; Emestova, L. S.; Kemp, T. J.; Skurlalov, Y. I.; Pyrmal, A. P.; Yermakov, A. N. Prog. React. Kinet. Mec. 1998, 23, 145.

10. Alfano, A. J.; Christe, K. O. Angew: Chem. Int. Ed. 2002, 41, 3252.

11. Alfano, A. J.; Christe, K. O. US Patent 6623718 B1, 2003.

12. Alfano, A. J.; Christe, K. O. USA AFRL report, AFRL-PR-EDTR-2004-0411, 2004 .

13. Khan, A. U.; Kasha, M. J. Am. Chem. Soc, 1970, 92, 3293.

14. Li, Q. W. Chen, F.; Zhao, W. L.; Duo, L. P.; Jin, Y. Q.; Sang, F. T. et al. High Power Laser and Particles Beam (Chinese) 2006, 18, 1761.

15. Jenny, T. A.; Turro, N. J. Tetrahedron Lett. 1982, 23, 2932.

16. Bromberg, A.; Foole, C. S. J. Phys, Chem, 1989, 9, 3968.

17. Schmidt, R.J. Phys. Chem, 1996, 100, 8049 .

18. Kajiwara, T.; Keams, D. R. J. Am. Chem. Soc. 1973, 95,5886 5890.

19. Rogers, M. A. J.; Snowden, P. T. J. Am. Chem. Soc. 1982, 104, 5541 .

20. Hursi, J. R.; McDonald, J. D.; Schuster, G. B. J. Am. Chem. Soc. 1982, $104,2065$.

21. Held, A. M.; Halko, D. J.; Hurst, J. K. J. Am. Chem. Soc. 1978, 100,5732 . 